\title{
İşgörenlerin Demografik Özelliklerinin Örgütsel İklim Algısına Etkisinin İstatistiksel Analizi: Süreyya Paşa Gögüs Hastalıkları Hastanesi Örneği
}

\author{
Cemil Örgev ${ }^{1}$, Bayram Topal ${ }^{2}$, Hasan Şahin ${ }^{3 *}$ \\ ${ }^{1}$ Sakarya Uygulamalı Bilimler Üniversitesi, Sağlık Bilimleri Fakültesi, Sağlık Yönetimi Bölümü, Sakarya, Türkiye (ORCID: 0000-0002-3521-4266) \\ ${ }^{2}$ Sakarya Üniversitesi, İsletme Fakültesi, İșletme Bölümü, Sakarya Türkiye (ORCID: 0000-0002-9027-0965) \\ ${ }^{3}$ Bandırma Onyedi Eylül Üniversitesi, Mühendislik ve Doğa Bilimleri Fakültesi, Endüstri Mühendisliği Bölümü, Bandırma/ Balıkesir, Türkiye (ORCID: 0000-0002- \\ $8915-000 X)$
}

(İlk Geliş Tarihi 26 Mart 2020 ve Kabul Tarihi 23 Mayıs 2020)

(DOI: 10.31590/ejosat.709785)

ATIF/REFERENCE: Örgev, C., Topal, B., \& Şahin, H. (2020). İşgörenlerin Demografik Özelliklerinin Örgütsel İklim Algısına Etkisinin İstatistik Analizi: Süreyya Paşa Göğüs Hastalıkları Hastanesi Örneği. Avrupa Bilim ve Teknoloji Dergisi, (19), 165-175.

Öz

İşletme olarak hastaneler, her türlü sağlık hizmetinin üretildiği, karmaşık yapılı ve yüksek düzeyde uzmanlaşmayı gerektiren sağlık kurumlarıdır. Hastaneler hem emek hem de sermaye yoğun işletme özelliğine sahip sağlık kurumlardır. Sağlık sektöründe giderek artan bir rekabet ortamı oluşmaktadır. Böyle bir ortamda rakiplerden önde olabilmek için örgütsel iklim ve örgütsel bağllık kadar bu iki kavramı etkileyen faktörler de son derece önemlidir. Bir örgütte çalışanların örgüt amaçlarını benimsemeleri, değer yargılarını kabul etmeleri, inanç ve kurallara uygun davranışlarda bulunmaları ve kendilerinden beklenen davranışları göstermelerinin anahtarı olarak "örgütsel iklim"; işletmelerin rekabet avantajı sağlayabilmeleri ve vasıflı iş görenleri bünyelerinde tutabilmeleri için ise "örgütsel bağlılık" vazgeçilmez olarak görülebilir. Bu çalışma sağlık çalışanlarının algıladıkları hizmetkâr liderlik anlayışı çerçevesinde örgütsel iklim ve örgütsel bağlılık arasında anlamlı bir ilişkinin var olup olmadığını belirlemek amacıyla yapılmıştır. Çalışma 30.10.2017 ile 30.12.2017 tarihleri arasında İstanbul İli Kamu Hastaneler Birliğine bağlı bir devlet hastanesinde aktif olarak çalışan 495 sağlık personelinden 254'üne uygulanmıştır. Örneklem, rastgele örneklem seçim tekniği olup katılım \%52,93'dür. Çalışmada veri toplama aracı olarak; Robert Stringer tarafindan geliştirilmiş, örgüt iklimi ölçeği; Meyer ve Allen tarafından geliştirilmiş örgütsel bağlılık ölçeği ve çalışanların sosyal-demografik niteliklerinden oluşan bir anket formu kullanılmıştır. Ölçek ve alt boyut puanları normal dağılım gösterdiğinden cinsiyet, medeni durum; yaş, öğrenim düzeyi, kadro durumu, kıdem, kamuda çalışma süresi, toplam aylık gelir değişkenlerine göre karşılaştırılmıştır. Gruplar arasındaki anlamlı farklılık için de ikili karşılaştırmalar yapılmıştır. Örgütsel iklim ölçeği ve alt boyut puanlarının hem cinsiyete hem de medeni duruma göre, aynı zamanda yaş gruplarına, öğrenim düzeyine, mesleki kıdemine, kamuda çalışma süresine göre anlamlı farklılık göstermediği belirlenmişsir.

Anahtar Kelimeler: Örgütsel İklim, Örgütsel Bağlılık, Hizmetkâr Liderlik, Müșteri Memnuniyeti.

\section{Statistical Analysis of the Impact of Employees' Demographic Characteristics on Organizational Climate Perception: The Case of Süreyya Paşa Chest Diseases Hospital}

\begin{abstract}
As an enterprise, hospitals are health institutions where all kinds of health services are produced, complex structured and requiring high level of specialization. Hospitals are both health-intensive and capital-intensive health institutions. There is an increasing competitive environment in the health sector. In this competitive environment, the factors affecting these two concepts are as important as the organizational climate and organizational commitment to be ahead of the competitors. "Organizational climate" is the key for people
\end{abstract}

*Sorumlu Yazar: Bandırma Onyedi Eylül Üniversitesi, Mühendislik ve Doğa Bilimleri Fakültesi, Endüstri Mühendisliği Bölümü, Bandırma/ Balıkesir, Türkiye, ORCID: 0000-0002-8915-000X, hsahin@bandirma.edu.tr 


\section{Avrupa Bilim ve Teknoloji Dergisi}

working in an organization to adopt organizational goals, accept value judgments, engage in relationships that conform to beliefs and norms, and demonstrate expected behavior. "Organizational commitment" can be seen as indispensable for enterprises to gain competitive advantage and to retain qualified employees. This study was conducted to determine whether there is a meaningful relationship between the perceived servant leadership understanding of healthcare personnel and organizational climate and organizational commitment. The study was applied to 254 out of 495 health personnel who were actively working in a public hospital affiliated with the Public Hospitals Association of Istanbul between 30.10.2017 and 30.12.2017. The sample was randomly selected and the participation rate was $52,93 \%$. In the study, servant leadership scale was used as a data collection tool; Organizational climate scale developed by Robert Stringer; Organizational commitment scale developed by Meyer and Allen and a questionnaire consisting of organizational commitment scale and social-demographic characteristics of employees. As the scale and subscale scores showed normal distribution, gender, marital status; age, education level, staff status, seniority, working time in public sector, total monthly income were compared. Pairwise comparisons were also made for the significant difference between the groups. It was found that the organizational climate scale and sub-dimension scores did not differ significantly according to both gender and marital status, age groups, education level, professional seniority, and duration of work in the public sector.

Keywords: Organizational Climate, Organizational Commitment, Servant Leadership, Customer Satisfaction.

\section{Giriş}

Dünya Sağlık Örgütü (DSÖ)'ye göre sağlık “sadece herhangi bir hastalık ve sakatlık halinin olmaması değil, fiziksel, ruhsal ve sosyal yönden tam bir iyilik hali” (Öztek, 2006) olarak tanımlamıştır. Örgüt iklimi; örgütün yapısını oluşturan, örgütüleri birbirinden ayıran, örgütü tasvir eden, örgüte hakim olan, örgütün iç yapısının son derece kararlı, değişmez, sürekli niteliğine sahip ve örgütteki bireylerin tutum ve davranışlarını etkileyen ve onlardan etkilenen, somut bir şekilde gözle görülüp elle tutulamayan, ancak örgütteki kişilerce hissedilip algılanabilen ve tüm bu özellikleri kapsayan psikolojik bir terim (Yüceler, 2009) olarak ifade edilebilir. Ayrıca örgüt iklimi kavramı çok boyutlu bir kavram olup; örgüt yapısı, örgütsel destek, sorumluluk, çatışma, ödül, risk, samimiyet, standartlar ve aidiyet kavramlarından oluşmaktadır (Demirbaş, 2017). Genellikle örgüt iklimi ile örgüt kültürü kavramları birbirinin yerine kullanılmaktadır. Örgütler kültür ve iklimlerini geliştirme aşamasında çeşitli gelenekler, yasaklar ve ahlak ilkelerinden faydalanırlar. Bir örgütün iklimi ve kültürü hem biçimsel örgütün davranış kalıplarını ve değerlerini hem de bunların doğal örgütteki yorumlarını ifade eder. Nasıl ki bir toplumun kültür bir mirası varsa, sosyal örgütlerde de örgüte yeni katılan üyelere bırakılan örgütle ilgili kalıplaşmış normlar ve değerler vardır (Güçlü, 2003).

Örgütsel iklimle ilgili bazıları tanımlar şunlardır: Acaray ve Pelenk (2018) göre iklim, belli bir yerde işgörenler tarafından hissedilen ve onların davranışlarını etkileyen tüm çevrenin özellikleridir. Karcıŏlu (2001) iklimi, "bir örgütü diğer bir örgütten ayıran özellikler veya nitelikler setini ifade eder" şeklinde tanımlanken devamında, "bu tanım, kişilik kavramına benzemekte olup, gerçekte örgüt iklimi, sık sık örgütün kişiliği olarak ima edilir” ifadesini kullanmaktadır. Örgütsel iklim, işgörenlerin örgütteki mevcut atmosferi algılaması sonucu ortaya çıkan, hissedilen ve ölçülebilen özelliklerin toplamıdır. Her örgütün kendine has bir iklimi, kimliği ve ortamı vardır (Deniz ve Çoban, 2016). Örgüt ikliminin için en yaygın tanımlardan bir diğerine göre örgüt iklimi, iş çevresinde işgörenler tarafından direkt veya endirekt olarak algılanan ve çalışanların davranış ve motivasyonlarını etkilediği düşünülen, ölçülebilir özellikler kümesidir (İşcan ve Karabey, 2007). Taymaz (2003)'e göre, bir örgütte örgütsel iklimin oluşmasında örgütsel kültürün önemli rol oynamaktadır. Örgüt iklimi; örgütün genel kişiliğini, örgüt üyelerinin ortak algılarını ve örgüt üyelerinin davranış ve tutumlarını etkilemek gibi özellikleri vardır (Saraç, 2015). Örgüt iklimle ilgili ilk referans Lewin ve arkadaşlarının genç grupların sosyal iklim yaratan tecrübelerinden söz eden çalışmalarıdır. Örgütsel iklimin işgörenler üzerindeki etkisine yönelik çalışmalar Hawthorne araştırmalarına kadar uzanmaktadır. Bu çalışmalarda, işgörenlerin motivasyonları, iş tatminleri, performansları ve verimlilikleri arasında ilişkiler belirlenmeye çalışılmış ve netice olarak çalışanların örgütsel iklimi olumlu algılamalarının performansları üzerinde de olumlu etkisinin olduğu belirlenmiştir (Tutar ve Altınöz, 2010). Tutar ve Altınöz (2010)’ün Zammuto ve Krackover'dan (1991) aktardığına göre, örgütsel iklimi ölçmek ve değerlendirmek için 7 farklı boyutan söz edilmektedir. Bunlar "güven, çatışma, birlik ruhu, ödüller, değişime direnç, lider güvenirliği ve baskı" olarak ifade edilmiştir. Örgüt iklimi, örgütsel değerler, normlar, inançlar, yöntem ve faaliyetlerle ilgili oluşan ortak bir algı olarak tanımlanmaktadır (Aşık, 2018). Örgütsel iklimin, açıklık, standartlar, sorumluluk, esneklik, ödüller ve takım taahhüdü şeklinde 6 farklı iklim boyutu olup Tablo 1'de gösterilmektedir (Nair, 2006). 
Tablo 1. Örgütsel İklim İçin Boyut ve Maddeler

\begin{tabular}{|c|c|}
\hline Boyut & Madde \\
\hline \multirow{2}{*}{ Açıklık } & Sizden ne beklendiğini bilmek, \\
\hline & Bu beklentilerin kurumun takım taahhüdü hedefleriyle nasıl ilişkili olduğunu anlamak. \\
\hline \multirow{3}{*}{ Standartlar } & Olumlu bir şekilde birlikte çalışmak ve örgütsel yapılar arasında iş birliği yapmak. \\
\hline & Zorlu ancak ulaşılabilir hedeflerin belirlendiği seviye, \\
\hline & Sıradanlığa tolerans gösterilmeyen kapsam. \\
\hline \multirow{3}{*}{ Sorumluluk } & Size yetki verilmiş olduğunu hissetmek, \\
\hline & İşinizi mikro yönetilmeden yapabileceğinizi hissetmek, \\
\hline & Hesap verebilirlik. \\
\hline \multirow{2}{*}{ Esneklik } & Gereksiz kurallar veya prosedürler olmadığını düşündüğünüz seviye, \\
\hline & Yeni fikirlerin kolay kabul edildiğini hissetmek. \\
\hline \multirow{2}{*}{ Ödüller } & İyi iş için tanınmak, \\
\hline & Tanınmanın doğrudan performans düzeyleriyle ilişkili olduğu derece. \\
\hline \multirow{3}{*}{ Takım Taahhüdü } & Organizasyona ait olmaktan gurur duyuyor ve gurur duyduğunu ifade ediyor, \\
\hline & Herkesin ortak bir hedefe doğru çalıştığına güvenmek, \\
\hline & Olumlu bir șekilde birlikte çalıșmak ve örgütsel yapıllar arasında iș birliği yapmak. \\
\hline
\end{tabular}

Örgütsel bağllık, hem ișletmelere rekabet avantajı sağlaması, hem de vasıflı iş gücünü istihdam edebilme ve sürekli bir aidiyet kazandırması bakımından olmazsa olmaz bir kavramdır (Örgev ve Sütlü, 2018). Örgütsel bağlılık hakkındaki ilk çalışmalar örgütsel bağll lı̆̆g örgütsel değerlerin benimsenmesini ifade eden tek boyutlu bir yapı olarak betimleseler de Meyer ve Allen örgütsel bağl1lığın duygusal, sürekli ve normatif bağlılık olmak üzere üç farklı boyuta sahip olduğunu saptamışlardır (Yüceler, 2009). Örgütsel bağlılıkta öncelikle örgütün hedef ve değerlerine içtenlikle inanış ve bunları kabulleniş, her şeyini örgütü için gönüllü olarak ortaya koyma ve örgüte üyeliğin sürekliliği noktasında güçlü bir iradenin oluşturulması gibi faktörler öne çıkmaktadır (Deniz ve Çoban, 2016).

Mowday, Porter ve Steers örgütsel bağl1lığ etkileyen üç faktörden bahsetmişlerdir. Bunları Kişisel faktörler, Örgütsel faktörler ve Örgütsel olmayan faktörler şeklinde ortaya koymuşlardır. Örgütsel bağlılık açısından psikolojik kontrat da önemlidir. Literatürde psikolojik kontrat, çalışanlarlarla örgüt arasında yazılı olmayan karşılıklı beklentilerin tümü şeklinde tanımlanmaktadır (Yağcı, 2007). Ayrıca örgütsel bağlılık, bireyin bir işletmeye veya eylemin seyrine bağlanma durumu olarak tanımlanırken başka bir ifadede ise işletmelerin hedeflerine ulaşması için çalışanların daha fazla çaba göstermesini sağlar şeklinde tanımlanmaktadır (Bulşu ve Gümüş, 2018).

Örgütsel bağlllık son 30 yılda Amerika başta olmak üzere birç̧ok ülkede araştırma konusu olmuştur. Giderek küçülen dünyada iktisadi ve ticari açıdan ülkeler arasında sınırların kalktığı, rekabetin arttı̆̆ı bir ortamda örgütlerin hayatta kalabilmeleri ve geleceğe daha güçlü adımlarla ilerleyebilmeleri için örgütsel bağlılık kavramının önemi daha da artmıştır (Çelik, 2012). Netice olarak örgütsel bağlllık, çalışanların kurumsal hedef ve değerleri kabul etmesi, bu hedeflere ulaşılması için gayret etmesi ve örgüt üyeliğgini sürdürme arzusudur. Bu bağlamda örgütsel bağll1ıkta esas olarak olarak üzerinde durulan faktörler: örgütten için her şeyini feda etmeye gönüllü olma, örgütün amaç ve değerlerine inanma ve nihayet örgütün bir üyesi olarak kalmaya istekliliktir (Yeniçeri ve Yücel, 2009).

Örgüt iklimi önemli kabul edilir: Bu konudaki algı, motive olmuş çalışanın daha yüksek verimlilikle, iş için daha fazla tutkuyla ve müşterilerle daha derin bir ilişki kurmasıyla sonuçlanacağı yönündedir. Olumlu bir iklim, çalışanların üretkenliğini teşvik eder ve çalışan sirkülasyonunu azaltır. Şekil 1, örgütsel iklimin performans üzerindeki etkisini açıklamaktadır (Permarupan ve ark., 2013).

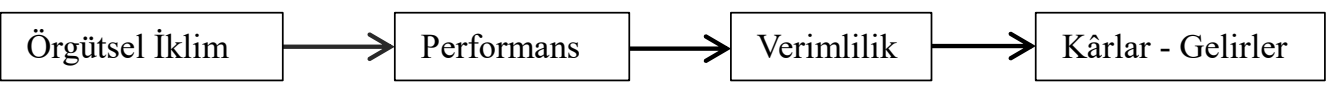

Şekil 1. Örgütsel iklimin performans üzerindeki etkisi

\section{Literatür İncelemesi}

Örgütsel iklim, "örgütsel hayatta farkına varılan ve tanımlanması güç olan bir duygusal etkileşim" (Mullins, 2007) olarak tanımlanabilir. Başka bir tanımda ise örgüt iklimi, "işgörenlerin deneyimlediği politika, uygulama ve prosedürlerin paylaşılan algılamaları ve anlamları ile ödüllendirildiği gözlemlenen, desteklenen ve beklenen davranışlar" (Yalçınsoy, 2016) olarak tanımlanabilir. Örgütsel iklim, örgüt kültürü gibi, örgütlerin kendilerine has özelliklerini yansıtmakta olup bu durum örgütün tüm departmanları için de geçerlidir. Örgüt ikliminin bir başka özelliği de, örgütün formal yapısına benzemeyip informel bir özelliğe sahip olmasıdır. Örgütün fiziksel yapısı tüm işgörenler tarafından aynı görülmesine karşın, psikolojik yapısını ifade eden örgütsel iklim algısı çalışan sayısınca farkl111lık gösterebilir (Tutar ve Altıöz, 2010). 
Literatür incelendiğinde örgüt iklimi ve çalışma hayatı arasındaki etkiyi inceleyen çok sayıda araştırma vardır. Fabiene ve Kachchhap (2016), Filipinler'de kantitaitif yöntemler kullanarak sağlık çalışanlarının iş tatminini etkileyen faktörlerle ilgili yaptıkları çalışmada örgütsel iklim ve örgütsel bağlılık arasında pozitif bir ilişkiye rastlanmıştır. Konaklama işletmelerinde çalışanların örgütsel bağlılıklarını etkileyen faktörlerin araştırıldığı bir çalışma yapılmıştır (Yağcı, 2007). Bu çalışmada otel çalışanlarının örgütsel bağlılık ve yaşam kalitesi düzeylerinin belirlenmesi amacıyla gerçekleştirilen bu çalışmada örgütsel bağlllık skorlarının cinsiyet, yaş, eğitim, medeni hal ve kıdem gibi bağımsız değişkenler açısından nasıl bir ilişki olduğu araştırılmış̧ır. Nojehdehi ve ark. (2016), İran'daki Tahran Tıp Bilimleri Üniversitesi'nde yaptıkları çalışmada, örgüt ikliminin örgütsel bağlılık ve işten ayrılma niyeti üzerinde endrekt etkisi olduğunu, örgüt iklimindeki olumlu bir değişmenin çalışanların işten ayrılma niyetinin azalmasına sebep olduğunu tesbit etmiştir. Günay ve ark. (2017), yapısal eşitlik modeli ile turizm sektöründeki yöneticilerin işkoliklik ve örgütsel iklim boyutları arasındaki nedensellik ilişkilerini araştırmıştır. Araştırmanın sonuçlarına göre örgütsel iklim alt boyutlarından bireysel sorumluluk alt boyutunun işkoliklik üzerinde etkili olduğu, ödüllendirme boyutunun işkoliklik alt boyutlarından sadece güdülenme üzerinde etkili olduğu saptamnmıştır. Uysal (2013), örgüt iklimi altındaki güven-saygı, liderin tutumu, tatmin olma, iletişim ve destek algısı alt faktörlerini mesleki bağlılık ile ilişkilendirmiştir. Buna göre örgüt ikliminin alt boyutları ile stajyer çalışanların mesleki bağglılık gelişimleri arasında anlamlı ilişkiler bulumuştur. Tsai, Tayvan'da yaptığı araştırmada çalışanların işletme türü ile örgütsel iklim'in yakından ilişkili olduğunu tespit etmiştir (Tsai, 2014).

Gürkan ve Koçoğlu (2014) hem vakıf hem de devlet üniversitesinde görev yapan öğretim elemanlarının yaratıcı örgüt iklimi algılarının kariyer tatminleri üzerindeki etkisinde duygusal bağlılığın kısmi aracı rolü olduğunu belirlemiştir. Güner (2015) çalışmasında örgütsel iklimin iş tatminine etkisini ve bu bağlamda iş görenin iş tatminini artıran etkenleri incelemiştir. Araştırma sonucu örgütsel iklim ve iş tatmini arasındaki anlamlı ve olumlu bir etkinin olduğunu belirlemiştir. Tutar (2016), örgütsel iklim alt boyutlarını, belirsizlik toleransı, çevresel faktörler, örgütsel iletişim, çalışan özellikleri, işin yapısı, liderlik türü, örgüt yapısı, amaçları, değer ve normları, yönetim şekli, güven ve destek, ödüllendirme ve cezalandırma, standartlar ve örgütsel ortamda tanınma olarak ortaya koymuştur. Deniz ve Çoban (2016), Malatya'da Esenlik Şirketi üretim departmanında 233 çalışan üzerinde yaptıkları araştırmada örgütsel iklim ile örgütsel bağlllık arasında pozitif yönde önemli bir ilişkinin olduğunu görmüşlerdir. Buna göre örgütsel iklimin, örgütsel bağlllık ve alt boyutlarını pozitif yönde etkilediğini ortaya saptanmıştır. Hashemi ve Sadeqi (2016)'nin İran'da yaptıkları araştırmada çalışanlar arasında örgütsel iklim bileşenleri ile iş tatmini arasındaki ilişkiyi incelemişler ve pozitif ilişki olduğu tespit etmişlerdir. Yüksekbilgili ve Küçüközkan (2017), sağlık kurumlarında çalışanların örgütsel iklimi algılarının iş performansları ile ilişkisini ve iş performansı üzerindeki etkisini belirlemişlerdir. Buna göre çalışanların olumlu örgüt iklimi algısının iş performansı ile anlamlı ve pozitif yönde olduğunu saptamışlardır. Ak (2018), Bartın İli'nde Bartın 112 acil sağlık hizmetleri istasyonları evreninde görev yapan personeller nezdinde gerçekleştirilen örgütsel iklim anketi sonucunda ortaya çıkan bulgulara yer vermiştir. Baş ve ark. (2018), Sağlık çalışanlarının örgütsel iklimin örgütsel bağlılığa etkisini incelemiş ve pozitif yönlü güçlü ilişki bulmuşlardır. Örgev ve Sütlü (2018), sağlık personelinin hizmetkâr liderlik algıları ile örgütsel iklim ve örgütsel bağlılık arasındaki ilişkilerini araştırmışlardır. Araştırma sonuçlarına göre hizmetkâr liderliğin örgütsel bağl1lı̆̆ anlamlı ve olumlu yönde etkilediği belirlenmiştir. Sarı (2019), yöneticilerin kullandıkları alg1 yönetimi taktiklerinin öğretmen motivasyonunu nasıl etkilediğini ve yöneticilerin kullandıkları alg1 yönetimi taktiklerinin öğretmen motivasyonuna etkisinin okul iklimine aracılık rolü tespit etmiş̧ir. Filiz ve Bardakçı (2020), sağlık çalışanlarının örgütsel iklim algıları ile örgütsel güven düzeyleri arasındaki ilişkiyi incelemişlerdir. Göreci (2019), İstanbul'da faaliyet gösteren bir otomotiv firmasından elde ettiği verilerden faydalanarak farklılıkların yönetimi ile örgüt iklimi arasındaki ilişkiyi incelemiştir. Kılıç (2019), etik iklimin, örgütsel bağlllık ve öğretmen performansı üzerindeki etkisini incelemiştir. Ertem ve Gökalp (2019), lisansüstü eğitim düzeyinde örgüt iklimini ölçmeye yönelik bir ölçek geliştirmişlerdir. Akgemci, Abdul-Kareem, Kızıloğlu (2020), çalı̧̧anların örgüt iklimine ilişkin algılarının örgüt temelli özsaygı ve öznel iyi oluş üzerindeki etkisini belirlemişlerdir. Ertürk ve Zıblım (2020), okullardaki örgütsel sapma algısının örgütsel iklim değişkeni tarafından yordanıp yordanmadığını belirlemeye çalışmışlardır. Mikail ve Çora (2020), örgüt ikliminin özel sağlık kuruluşlarında hizmet kalitesi üzerine etkilerini incelemişlerdir. Buna göre örgütsel iklimin, örgütsel bağlılık ve alt boyutlarını pozitif yönde etkilediği saptanmıştır.

\section{Uygulama}

\subsection{Araştırmanın Amaç ve Kapsamı}

Sağlık işletmelerinde özellikle hastanelerde (kamu veya özel) gerek medikal teknoloji gücü gerekse vasıflı iş gücü yönünden giderek artan bir rekabet ortamı oluşmaktadır. Bu pazarda tercih edilip rakiplerin önüne geçebilmek için gerekli olan "örgütsel iklim ve örgütsel bağlılık" kadar bu iki kavrama anlam veren unsurlar da önem arzetmektedir. Çalışma ile sağlık çalışanlarının algıladıkları hizmetkâr liderlik anlayışı çerçevesinde çalışanların demografik özellikleri ile örgütsel iklim ve alt boyutları örgütsel katılım ve örgütsel bağllık arasındaki ilişkilerin varlığının araştırılması amaçlanmıştır.

Bu çalışma 30.10.2017 ile 30.12.2017 tarihleri arasında aktif olarak 495 kişinin çalışıı̆̆ İstanbul İli Kamu Hastaneler Birliğine bağlı bir devlet hastanesinde 254 sağlık personeline uygulanmıştır. Rastgele örneklem seçim tekniği ile Örneklem oluşturulmuş̧ur. Verilerin toplanmasında hizmetkâr liderlik ölçeği; Robert Stringer tarafindan geliştirilmiş, örgütsel iklim ölçeği; Meyer ve Allen tarafindan geliştirilen örgütsel bağlılık ölçeği ve çalışanların sosyal-demografik özelliklerini içeren bir anket formu kullanılmıştır. Anketin geçerli ve güvenilir olduğu, "için örgütsel iklim" ve "örgütsel bağlllık" ölçeklerinin geçerlilik ve güvenilirlik analizleri yapılarak belirlenmiştir. Sonuçların değerlendirilmesinde, SPSS aracılığıyla, betimsel istatistikler, korelasyon analizi, regresyon analizi, ANOVA ve $t$ testi gibi analizler kullanılmıştır.

\subsection{Araştırmanın Hipotezleri}

Araştırmanın amacı doğrultusunda aşağıdaki hipotezler geliştirilmiş̧ir.

$\mathrm{H}_{1}$ : Çalışanların örgütsel iklim algısı cinsiyete göre farklılık göstermektedir.

e-ISSN: 2148-2683 
$\mathrm{H}_{2}$ : Çalışanların örgütsel iklim algısı medeni durumua göre farklılık göstermektedir.

$\mathrm{H}_{3}$ : Çalışanların örgütsel iklim algısı yaşa göre farklılık göstermektedir.

$\mathrm{H}_{4}$ : Çalışanların örgütsel iklim algısı öğrenim düzeyine göre farklılık göstermektedir.

$\mathrm{H}_{5}$ : Çalışanların örgütsel iklim algısı kadro pozisyonuna göre farklılık göstermektedir.

$\mathrm{H}_{6}$ : Çalışanların örgütsel iklim algısı kıdeme göre farklılık göstermektedir.

$\mathrm{H}_{7}$ : Çalışanların örgütsel iklim algısı kamu sektöründe çalışma süresine göre farklılık göstermektedir..

$\mathrm{H}_{8}$ : Çalışanların örgütsel iklim algısı gelir düzeyine göre farklılık göstermektedir.

\subsection{Veri Toplama Aracı}

Araştırmada anket formu iki bölümden oluşturulmuştur. İlk bölümde cinsiyet, yaş, medeni durum, öğrenim düzeyi, kadro durumu, kıdem, kamuda çalışma süresi, toplam aylık gelir gibi katılımcıların demografik niteliklerini belirlemeye dönük sorulara yer verilmiştir. Anketin ikinci bölümde hizmetkâr liderlik ölçeği; Robert Stringer tarafından geliştirilmiş, örgütsel iklim ölçeği; Meyer ve Allen tarafindan geliştirilen örgütsel bağlılık ölçeğinden oluşan (Özdemir, 2006; Ak, 2018) sorulardan oluşmuştur. Ölçek beşli Likert tipinde (1: hiç katılmıyorum, 5: kesinlikle katılıyorum) cevap seçeneklerini içermektedir. Alt boyut ve ölçek genelinde yüksek puan, örgütsel iklime ilişkin algının yüksek düzeyde olumlu olduğunu ifade etmektedir. Cronbach Alpha katsayısı ölçeğin tümü için 0,79; alt boyutlardan katılım için 0,79 ve bağlılık için 0,62 olarak tespit edilmiştir.

\subsection{Veri Analizi}

Verilerin analizinde SPSS 21.0 yazılımı kullanılmıştır. Verinin normalliğinin sınamasında çeşitli testler kullanılmaktadır. Normal dağılım göstermeyen veriler karekök, logaritmik veya ters dönüşüm yöntemleri kullanılarak normalleştirilerek parametrik testler kullanılabileceği gibi non-parametrik testler de kullanılabilir (Büyüköztürk, 2011). Parametrik testler non-parametrik testlere göre daha güçlü olduklarından tercih edilirler. Yapılan normallik sınamasına göre (Tablo 2) verilerin normal dağıldığı anlaşılmıştır. Buna göre ölçek ve alt boyutlarının cinsiyet, medeni hal şıklarına göre karşılaştırılmasında bağımsız örneklemler t testinden; yaş, öğrenim düzeyi, kadro durumu, kıdem, kamuda çalışma süresi, toplam aylık gelir değişkenlerinin şıklarına göre karşılaştırılmasında tek yönlü varyans analizi (ANOVA) kullanılmıştır. ANOVA testinde gruplar arasında anlamlı farklılık olması halinde farkın hangi gruplardan kaynaklandığını belirlemek amacıyla ikili karşılaştırmalar için LSD post hoc testi kullanılmıştır. Analizlerde anlamlılık seviyesi 0,05 $(\mathrm{p}<0,05)$ olarak uygulanmıştır.

Tablo 2. Normallik Testi

\begin{tabular}{c|c|c|c|c|c|c}
\hline \multirow{2}{*}{ Alt Boyut } & \multicolumn{3}{|c|}{ Kolmogorov-Smirnov } & \multicolumn{3}{c}{ Shapiro-Wilk } \\
\cline { 2 - 7 } & İstatistik & Serbestlik derecesi & Anlamlılık & İstatistik & Serbestlik derecesi & Anlamlılık \\
\hline Katılım &, 057 & 203 &, $200^{*}$ &, 988 & 203 &, $096^{*}$ \\
\hline Băglılık &, 096 & 203 &, 000 &, 986 & 203 &, $052^{*}$ \\
\hline Toplam &, 062 & 203 &, $064^{*}$ &, 984 & 203 &, 022 \\
\hline
\end{tabular}

(*) Normal dağılım gösteriyor.

\section{Bulgular ve Analizler}

\subsection{Betimleyici İstatistikler}

Tablo 3'de katılımcıların demografik özelliklerinin frekans ve yüzde dağılımı gösterilmiştir. 


\begin{tabular}{|c|c|c|c|}
\hline Demografik Değişken & Grup & $\mathbf{n}$ & $\%$ \\
\hline \multirow{2}{*}{ Cinsiyet } & Kadın & 139 & 68,5 \\
\hline & Erkek & 64 & 31,5 \\
\hline \multirow{2}{*}{ Medeni durum } & Evli & 85 & 41,9 \\
\hline & Bekâr & 118 & 58,1 \\
\hline \multirow{3}{*}{ Yaş } & $20-29$ yaş & 72 & 35,5 \\
\hline & $30-39$ yaş & 97 & 47,8 \\
\hline & $40-49$ yaş & 34 & 16,7 \\
\hline \multirow{3}{*}{ Öğrenim düzeyi } & Lise & 89 & 43,8 \\
\hline & Ön lisans & 39 & 19,2 \\
\hline & Lisans & 75 & 36,9 \\
\hline \multirow{3}{*}{ Kadro durumu } & Sağlık hizmetleri & 100 & 49,3 \\
\hline & İdari hizmetler & 22 & 10,8 \\
\hline & Yardımcı hizmetler & 81 & 39,9 \\
\hline \multirow{4}{*}{ Mesleki kıdem } & 1 yıldan az & 67 & 33,0 \\
\hline & $1-5$ y1l & 41 & 20,2 \\
\hline & $5-8$ y1l & 56 & 27,6 \\
\hline & 9 yıl ve üstü & 39 & 19,2 \\
\hline \multirow{4}{*}{ Kamuda çalışma süresi } & $1-5$ y1l & 36 & 17,7 \\
\hline & $6-10$ y1l & 57 & 28,1 \\
\hline & $11-15$ y1l & 77 & 37,9 \\
\hline & $16-20$ y1l & 33 & 16,3 \\
\hline \multirow{3}{*}{ Aylık gelir } & 3000TL ve alt1 & 42 & 20,7 \\
\hline & $3001-4000 \mathrm{TL}$ & 104 & 51,2 \\
\hline & 4001TL ve üstü & 57 & 28,1 \\
\hline
\end{tabular}

Tablo 3'e göre araştırmaya katılan 203 kişiden \%68,5'i gibi önemli bir kısmı kadınlardan oluşmaktadır. Katılımcıların \%58,1'inin bekâr, \%83,3'ünün 39 yaş altında olduğu görülmüştür. Eğitim düzeyi açısından katılımcıların \%43,8'i lise, \%19,2'si ön lisans, \%36,9'u lisans düzeyinde öğrenim görmüştür. Katılımcıların \%49,3'ü sağlık hizmetleri, \%10,8'i idari hizmetler, \%39,9'i yardımcı hizmetler kadrosundadır. Katılımcıların \%50,3’ü 5 yıldan daha az kıdeme sahip iken, \%54,2’si en az 11 yıldır kamu sektöründe çalışmaktadır. Katılımciların \%20,7'sinin aylık geliri 3000TL ve altı, \%51,2'sinin 3001-4000TL, \%28,1'inin 4001TL ve üstüdür.

Tablo 4'de ölçek ve alt boyutlarını tasvir eden ortalama, standart sapma ve çarpıklık (Skewness), basıklık (Kurtosis) ölçüleri verilmiştir.

Tablo 4. Ölçeklere Ait Betimleyici Istatistikler

\begin{tabular}{c|c|c|c|c|c|c|c}
\hline Alt Boyut & $\mathbf{n}$ & Min. & Maks. & $\overline{\mathbf{X}}$ & SS & Çarpıklık & Basıklık \\
\hline Katılım & 203 & 2,09 & 4,82 & 3,52 & 0,52 & $-0,32$ & 0,437 \\
\hline Bağlılık & 203 & 1,33 & 5,00 & 3,46 & 0,57 & 0,07 & $-0,104$ \\
\hline TOPLAM & 203 & 1,85 & 4,83 & 3,49 & 0,49 & 0,10 & 0,525 \\
\hline
\end{tabular}

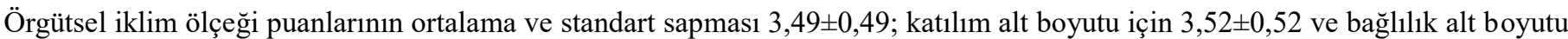

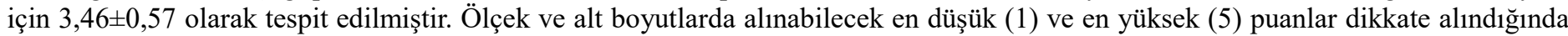
katılımcıların örgütsel iklim algısının "yüksek düzeyde olumlu” olduğu söylenebilir (Ölçek ve alt boyutlardan alınabilecek en düşük (1) ve en yüksek (5) puanlara göre düzey aralıkları 5-1=4/5=0,80; 1,0-1,80: "çok düşük"; 1,81-2,60: "düşük"; 2,61-3,40: "orta"; 3,41-4,20: “yüksek”; 4,21-5,00: “çok yüksek”) (Tablo 4). Benzer şekilde örgütsel iklim alt boyutları katılım ve bağlılık algısının da yüksek düzeyde olumlu olduğu anlaşılmaktadır.

\section{2. Örgütsel İklim Ölçeği Maddeleri İçin Analiz Sonuçları}

Örgütsel iklim ölçeği alt maddeleri ile ilgili olarak yapılan tek örneklem t testi sonucunda 4 alt maddede işgörenlerin büyük oranda pozitif bir görüşe sahip oldukları belirlenmiştir. Bu 4 alt madde "Yöneticiler işlerine çok önem vermektedirler" ( $\mathrm{t}=4,59$; $\mathrm{p}=0,000)$, "Yöneticiler ve işgörenler, işle ilgili hedefleri ve sorumlulukları paylaşmaktadırlar" ( $\mathrm{t}=2,94$; $\mathrm{p}=0,004)$, "Yöneticiler çalışanlardan gelen yeni fikirleri ciddiye alır ve uygularlar" $(\mathrm{t}=3,41 ; \mathrm{p}=0,001)$ ve "Yöneticiler tüm çalışanlara karşı saygılı davranmaktadırlar" ( $\mathrm{t}=2,91 ; \mathrm{p}=$ 0,004 ) pozitif ve anlamlı olup çalışanların yöneticilerinden genel olarak memnun oldukları anlaşılmaktadır.

Ayrıca cinsiyet ve medeni durum açısından örgütsel iklim ölçeği maddelerine uygulanan bağımsız örneklemler $t$ testi sonuçlarına göre bir madde dışında anlamlı bir farka rastlanmamıştır. Buna göre cinsiyete göre "Başka bir kurumdan teklif gelse bile çoğu çalışan, burada çalışmayı tercih eder” maddesinde anlamlı bir fark gözlenmiştir $(t=-2,83 ; p=0,005)$. Kadınların bu düşünceyi erkeklere göre 
daha fazla desteklemiştir. Buna göre kadınların örgütsel bağlllı̆̆ının erkeklere göre daha yüksek olduğu anlaşılmıştır. Yine medeni hal faktörüne göre yapılan $t$ testinde "Başka bir kurumdan teklif gelse bile çoğu çalışan, burada çalışmayı tercih eder" maddesinde anlamlı bir fark gözlenmiştir $(t=-3,144 ; \mathrm{p}=0,002)$. Bu sonuç bekârların evlilere göre bu düşünceyi daha yüksek düzeyde desteklediklerini ve örgütsel bağll1ıklarının evlilere göre daha yüksek olduğunu göstermektedir.

İkiden fazla grubun farkı için ANOVA testi yapılmış olup yaş gruplarına, öğrenim durumlarına ve çalışanların kadro durumuna göre örgütsel iklim ölçek maddeleri puanları arasında anlamlı bir fark bulunmamıştır. Ancak örgütsel bağlılık maddelerinden sadece "Yöneticiler çalışanlardan gelen yeni fikirleri ciddiye alıp ve uyguladıkları" konusunda çalışanların kıdemine göre ( $\mathrm{F}=2,91 ; \mathrm{p}=0,021)$ farklılık olduğu görülmüştür. Bu konuda kıdemi fazla olan çalışanların daha olumlu bir görüşe sahip oldukları anlaşılmıştır.

Gelir seviyesine göre örgütsel iklim maddelerinin farkı için uygulanan ANOVA testine göre sadece "Yöneticiler ve çalışanlar arasında iyi iş ilişkileri vardır" maddesinde farklılığa rastlanmıştır $(\mathrm{F}=3,51 ; \mathrm{p}=0,016)$. Bu konuda daha çok yüksek gelirli çalışanların daha olumlu görüşe sahip oldukları anlaşılmaktadır. Sonuç olarak gelir düzeyinin yükseklimesiyle çalışanların yönetimden memnuniyetler de artış göstermektedir.

\section{3. Örgütsel İklim ve Alt Boyutlarının Demografik Özelliklere Göre Karşılaştırılması}

Örgütsel iklim ölçeği ve alt boyut puanlarının kişilerin cinsiyetine vasfının şıklarına göre karşılaştırılması için bağımsız örneklem t testi yapılmış ve sonuçlar tablo 5 'te verilmiştir.

Tablo 5. Örgütsel İklim ve Alt Boyutlarının Cinsiyet Vasfinın Şıklarına Göre Karşılaştırlması

\begin{tabular}{|c|c|c|c|c|c|c|}
\hline Alt Boyut & Cinsiyet & $\mathbf{N}$ & $\overline{\mathbf{x}}$ & SS & $\mathbf{t}$ & $\mathbf{P}$ \\
\hline \multirow{2}{*}{ Katılım } & Kadın & 139 & 3,55 & 0,51 & \multirow{2}{*}{1,06} & \multirow{2}{*}{0,291} \\
\hline & Erkek & 64 & 3,46 & 0,55 & & \\
\hline \multirow{2}{*}{ Băğlllık } & Kadın & 139 & 3,49 & 0,56 & \multirow{2}{*}{1,05} & \multirow{2}{*}{0,292} \\
\hline & Erkek & 64 & 3,40 & 0,60 & & \\
\hline \multirow{2}{*}{ TOPLAM } & Kadın & 139 & 3,52 & 0,48 & \multirow{2}{*}{1,18} & \multirow{2}{*}{0,238} \\
\hline & Erkek & 64 & 3,43 & 0,51 & & \\
\hline
\end{tabular}

Tablo 5'e göre örgütsel iklim ölçeği ve alt boyut puanlarının cinsiyete göre anlamlı farkl1lık göstermediği (p>0,05) tespit edildiğinden "örgütsel iklim" konusunda kadınların ve erkeklerin benzer bir algıya sahip oldukları söylenebilir.

Örgütsel iklim ve alt boyutlarına ait puanlarının katılımcıların medeni durumuna göre karşılaştırılmış bağımsız iki örneklem $t$ testi ile yapılmış ve sonuçlar tablo 6'da verilmiş̧ir.

Tablo 6. Örgütsel İklim ve Alt Boyutlarının Medeni Durumun Şıklarına Göre Karşılaştırılması

\begin{tabular}{|c|c|c|c|c|c|c|}
\hline Alt Boyut & Medeni Durum & $\mathbf{N}$ & $\overline{\mathbf{X}}$ & SS & $\mathbf{t}$ & $\mathbf{P}$ \\
\hline \multirow{2}{*}{ Katılım } & Evli & 85 & 3,50 & 0,49 & \multirow{2}{*}{$-0,52$} & \multirow{2}{*}{0,601} \\
\hline & Bekar & 118 & 3,54 & 0,55 & & \\
\hline \multirow{2}{*}{ Băğlılık } & Evli & 85 & 3,44 & 0,45 & \multirow{2}{*}{$-0,36$} & \multirow{2}{*}{0,720} \\
\hline & Bekar & 118 & 3,47 & 0,65 & & \\
\hline \multirow{2}{*}{ TOPLAM } & Evli & 85 & 3,47 & 0,41 & \multirow{2}{*}{$-0,49$} & \multirow{2}{*}{0,624} \\
\hline & Bekar & 118 & 3,50 & 0,54 & & \\
\hline
\end{tabular}

Yukarıdaki tablodan görüleceği üzere örgütsel iklim ölçeği ve alt boyut puanlarının medeni duruma göre anlamlı farklılık göstermediği $(\mathrm{p}>0,05)$ tespit edilmiştir Kişilerin medeni haline göre örgütsel iklim algısı farklılık göstermemektedir.

Tablo 7'de örgütsel iklim ve alt boyut puanlarının katılımcıların yaş gruplarına göre farklılığını belirlemek için yapılan ANOVA testi verilmiştir.

Tablo 7. Örgütsel İklim ve Alt Boyutlarının Yaş Gruplarına Göre Karşılaştırılması

\begin{tabular}{|c|c|c|c|c|c|c|}
\hline Alt Boyut & Yaş Grubu & $\mathbf{N}$ & $\overline{\mathbf{X}}$ & SS & $\mathbf{F}$ & $\mathbf{P}$ \\
\hline \multirow{3}{*}{ Katılım } & A-20-29 yaş & 72 & 3,46 & 0,51 & \multirow{3}{*}{1,02} & \multirow{3}{*}{0,361} \\
\hline & B-30-39 yaş & 97 & 3,57 & 0,49 & & \\
\hline & $\mathrm{C}-40-49$ yaş & 34 & 3,48 & 0,64 & & \\
\hline \multirow{3}{*}{ Bağlllık } & A- $20-29$ yaş & 72 & 3,38 & 0,57 & \multirow{3}{*}{1,84} & \multirow{3}{*}{0,162} \\
\hline & B-30-39 yaş & 97 & 3,54 & 0,55 & & \\
\hline & $\mathrm{C}-40-49$ yaş & 34 & 3,40 & 0,61 & & \\
\hline \multirow{3}{*}{ TOPLAM } & A-20-29 yaș & 72 & 3,42 & 0,48 & \multirow{3}{*}{1,78} & \multirow{3}{*}{0,171} \\
\hline & B-30-39 yaş & 97 & 3,56 & 0,46 & & \\
\hline & C-40-49 yaş & 34 & 3,44 & 0,56 & & \\
\hline
\end{tabular}


Tablo 7'den örgütsel iklim ölçeği ve alt boyutları katılım ve bağlılık puanlarının yaş gruplarına göre anlamlı farklılık göstermediği $(p>0,05)$ tespit edilmiştir. Buna göre sağlık çalışanlarının örgütsel iklim algısı yaşa göre farklılık göstermemektedir.

Örgütsel iklim ölçeği ve alt boyutları katılım ve bağlılık puanlarının katılımcıların öğrenim düzeyine göre farklılık gösterip göstermediği ANOVA testi ile araştırılmış ve sonuçlar Tablo 8'de verilmiştir.

Tablo 8. Örgütsel İklim ve Alt Boyutlarının Öğrenim Düzeylerine Göre Karşılaştırılması

\begin{tabular}{|c|c|c|c|c|c|c|}
\hline Alt Boyut & Öğrenim Düzeyi & $\mathbf{N}$ & $\overline{\mathbf{X}}$ & SS & $\mathbf{F}$ & $\mathbf{P}$ \\
\hline \multirow{3}{*}{ Katılım } & A-Lise & 89 & 3,45 & 0,53 & \multirow{3}{*}{1,85} & \multirow{3}{*}{0,160} \\
\hline & B-Ön lisans & 39 & 3,53 & 0,57 & & \\
\hline & C-Lisans & 75 & 3,60 & 0,48 & & \\
\hline \multirow{3}{*}{ Băğlllık } & A-Lise & 89 & 3,40 & 0,54 & \multirow{3}{*}{0,92} & \multirow{3}{*}{0,401} \\
\hline & B-Ön lisans & 39 & 3,50 & 0,67 & & \\
\hline & C-Lisans & 75 & 3,51 & 0,55 & & \\
\hline \multirow{3}{*}{ TOPLAM } & A-Lise & 89 & 3,42 & 0,48 & \multirow{3}{*}{1,63} & \multirow{3}{*}{0,199} \\
\hline & B-Ön lisans & 39 & 3,51 & 0,56 & & \\
\hline & C-Lisans & 75 & 3,56 & 0,45 & & \\
\hline
\end{tabular}

Örgütsel iklim ölçeği ve alt boyutları katılım ve bağlılık puanlarının öğrenim düzeyine göre anlamlı bir farklılık göstermediği ( $p>0,05)$ yukarıdaki tablodan görülmektedir. Eğitim düzeyine göre örgütsel iklim algısı önemli bir fark göstermemektedir.

Örgütsel iklim ölçeği ve alt boyutları puanlarının katılımcıların çalıştığı kurumdaki kadro pozisyonuna göre farklılık gösterip göstermediği ANOVA testine göre analiz edilmiş ve sonuçlar tablo 9'da verilmiştir.

Tablo 9. Örgütsel İklim ve Alt Boyutlarının Kadro Durumuna Göre Karşılaştırılması

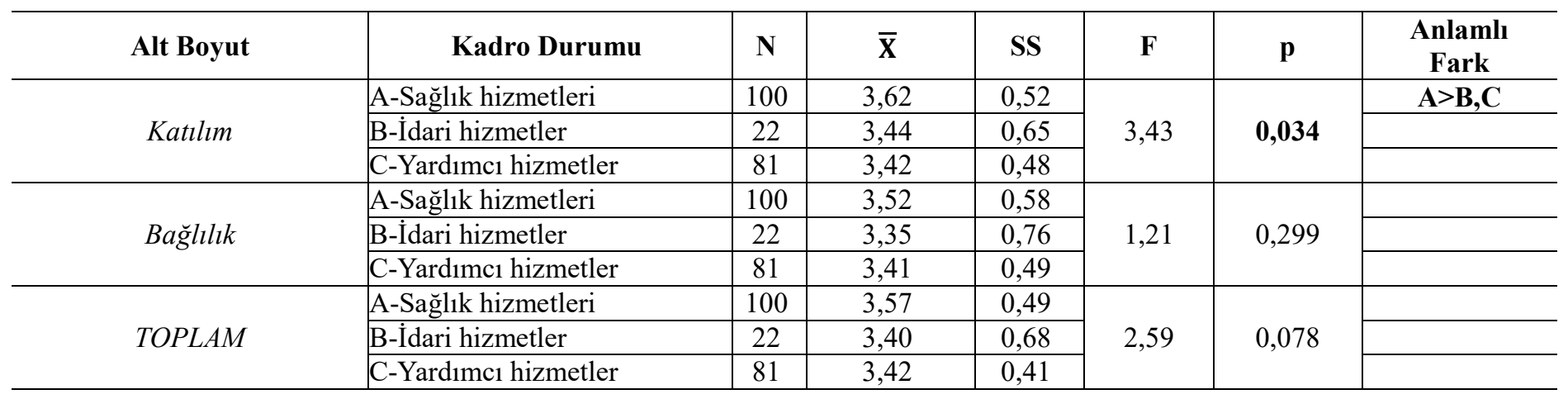

Yukarıdaki tabloya göre katılım alt boyut puanlarının kadro pozisyonlarına göre anlamlı farklılık gösterdiği tespit edilmiştir $(\mathrm{F}=3,43 ; \mathrm{p}<0,05)$. Sağlık hizmetleri kadrosunda yer alan katılımcıların katılım alt boyut puanları, idari hizmetler ve yardımc 1 hizmetler kadrolarındaki katılımcıların puanlarından anlamlı düzeyde yüksektir. Şu halde örgütsel iklim toplam puanları ve alt boyutu bağlılık puanları sağlık çalışanlarının kadro pozisyonlarına göre önemli bir fark göstermemektedir.

Örgütsel iklim ölçeği ve alt boyutları katılım ve bağlılık puanlarının katılımcıların mesleki kıdemine göre karşılaştırılması ANOVA testi ile araştırılmış ve sonuçlar Tablo 10’da verilmiştir. 
Tablo 10. Örgütsel İklim ve Alt Boyutlarının Mesleki Kıdeme Göre Karşılaştırılması

\begin{tabular}{|c|c|c|c|c|c|c|c|}
\hline Alt Boyut & Mesleki Kıdem & $\mathbf{N}$ & $\overline{\mathbf{X}}$ & SS & $\mathbf{F}$ & $\mathbf{p}$ & $\begin{array}{c}\text { Anlamlı } \\
\text { Fark }\end{array}$ \\
\hline \multirow{4}{*}{ Kattlım } & A-1 yıldan az & 67 & 3,44 & 0,48 & \multirow{4}{*}{1,74} & \multirow{4}{*}{0,161} & \\
\hline & B-1-5 yıl & 41 & 3,48 & 0,47 & & & \\
\hline & C-5-8 y1l & 56 & 3,65 & 0,55 & & & \\
\hline & D-9 yıl ve üstü & 39 & 3,51 & 0,59 & & & \\
\hline \multirow{4}{*}{ Băğlllık } & A-1 yıldan az & 67 & 3,43 & 0,48 & \multirow{4}{*}{1,73} & \multirow{4}{*}{0,162} & \\
\hline & B-1-5 y1l & 41 & 3,43 & 0,55 & & & \\
\hline & C-5-8 y1l & 56 & 3,60 & 0,60 & & & \\
\hline & D-9 yıl ve üstü & 39 & 3,34 & 0,67 & & & \\
\hline \multirow{4}{*}{ TOPLAM } & A-1 yıldan az & 67 & 3,43 & 0,41 & \multirow{4}{*}{1,96} & \multirow{4}{*}{0,122} & \\
\hline & B-1-5 y1l & 41 & 3,45 & 0,45 & & & \\
\hline & C-5-8 yil & 56 & 3,62 & 0,51 & & & \\
\hline & D-9 yıl ve üstü & 39 & 3,43 & 0,59 & & & \\
\hline
\end{tabular}

Yukarıdaki tablodan örgütsel iklim ve alt boyutları katılım ve bağlılık puanlarının mesleki kıdeme göre anlamlı farklılık göstermediği $(\mathrm{p}>0,05)$ tespit edilmiş olup mesleki kıdemin (tecrübe) Örgütsel iklim algısı üzerinde önemli bir farklılı̆ga sebep olmadığı anlaşılmaktadır.

Örgütsel iklim ölçeği ve alt boyut puanlarının katılımcıların kamuda çalışma süreslerine göre karşılaştırılması ANOVA testi ile araştırılmış ve sonuçlarına Tablo 11 'de verilmiş̧ir.

Tablo 11. Örgütsel İklim ve Alt Boyutlarının Kamuda Çalışma Sürelerine Göre Karşılaştırılması

\begin{tabular}{|c|c|c|c|c|c|c|c|}
\hline Alt Boyut & $\begin{array}{c}\text { Kamuda Çalışma } \\
\text { Süresi }\end{array}$ & $\mathbf{N}$ & $\overline{\mathbf{X}}$ & SS & $\mathbf{F}$ & $\mathbf{p}$ & $\begin{array}{c}\text { Anlamlı } \\
\text { Fark }\end{array}$ \\
\hline \multirow{4}{*}{ Katılım } & A-1-5 y1l & 36 & 3,55 & 0,48 & \multirow{4}{*}{1,01} & \multirow{4}{*}{0,392} & \\
\hline & B-6-10 y1l & 57 & 3,55 & 0,50 & & & \\
\hline & C-11-15 y1l & 77 & 3,44 & 0,56 & & & \\
\hline & D-16 yıl ve üstü & 33 & 3,61 & 0,53 & & & \\
\hline \multirow{4}{*}{ Băğlllık } & A-1-5 y1l & 36 & 3,46 & 0,49 & \multirow{4}{*}{0,19} & \multirow{4}{*}{0,902} & \\
\hline & B-6-10 y1l & 57 & 3,50 & 0,61 & & & \\
\hline & C-11-15 y1l & 77 & 3,42 & 0,57 & & & \\
\hline & D-16 y1l ve üstü & 33 & 3,46 & 0,60 & & & \\
\hline \multirow{4}{*}{ TOPLAM } & A-1-5 y1l & 36 & 3,51 & 0,42 & \multirow{4}{*}{0,54} & \multirow{4}{*}{0,654} & \\
\hline & B-6-10 y1l & 57 & 3,52 & 0,51 & & & \\
\hline & C-11-15 y1l & 77 & 3,43 & 0,51 & & & \\
\hline & D-16 yll ve üstü & 33 & 3,54 & 0,50 & & & \\
\hline
\end{tabular}

Yukarıdaki tabloya göre örgütsel iklim ölçeği ve alt boyut puanlarının kamuda çalışma süresine göre anlamlı bir farklılık göstermediği $(\mathrm{p}>0,05)$ saptanmıştır.

Örgütsel iklim ölçeği ve alt boyut puanlarının katılımcıların aylık gelirdüzeylerine göre farklılığı ANOVA testi ile araştırılmış ve sonuçları Tablo 12'de verilmiştir.

Tablo 12. Örgütsel İklim ve Alt Boyutlarının Ayllk Gelir Düzeylerine Göre Karşılaştırllması

\begin{tabular}{|c|c|c|c|c|c|c|c|}
\hline Alt Boyut & Aylık Gelir & $\mathbf{N}$ & $\overline{\mathbf{X}}$ & SS & $\mathbf{F}$ & $\mathbf{p}$ & $\begin{array}{c}\text { Anlamlı } \\
\text { Fark }\end{array}$ \\
\hline \multirow{3}{*}{ Katıllım } & A-3000TL ve alt1 & 42 & 3,36 & 0,48 & \multirow{3}{*}{5,37} & \multirow{3}{*}{0,005} & $\mathbf{C}>\mathbf{A}, \mathbf{B}$ \\
\hline & B-3001-4000TL & 104 & 3,49 & 0,54 & & & \\
\hline & C-4001TL ve üstü & 57 & 3,69 & 0,48 & & & \\
\hline \multirow{3}{*}{ Bağlllık } & A-3000TL ve altt & 42 & 3,38 & 0,43 & \multirow{3}{*}{2,11} & \multirow{3}{*}{0,123} & \\
\hline & B-3001-4000TL & 104 & 3,42 & 0,61 & & & \\
\hline & C-4001TL ve üstü & 57 & 3,59 & 0,58 & & & \\
\hline \multirow{3}{*}{ TOPLAM } & A-3000TL ve alt1 & 42 & 3,37 & 0,39 & \multirow{3}{*}{4,31} & \multirow{3}{*}{0,015} & $\mathbf{C}>\mathbf{A}, \mathbf{B}$ \\
\hline & B-3001-4000TL & 104 & 3,45 & 0,52 & & & \\
\hline & C-4001TL ve üstü & 57 & 3,64 & 0,47 & & & \\
\hline
\end{tabular}

Tablo 12 'de görüldüğü üzere örgütsel iklim toplam $(\mathrm{F}=4,31 ; \mathrm{p}=0,015)$ ve katılım alt boyutu puanlarının $(\mathrm{F}=5,37 ; \mathrm{p}<0,05)$ aylık gelir düzeyine göre anlamlı farklılık gösterdiği tespit edilmiştir. Aylık geliri 4000TL ve üstü olan katılımcıların örgütsel iklim ve katılım 
alt boyutu puanları, aylık geliri 4000TL altında olan katılımcıların puanlarından anlamlı düzeyde daha yüksektir. Buna göre yüksek ücret alan sağlık çalışanlarının örgütsel iklim ölçeği ve katılım alt boyutu için daha pozitif bir görüşe sahip olduğu anlaşılmaktadır. Ancak, bağll1ık alt boyutu puanlarında gelir düzeyine göre önemli bir farka rastlanmamıştır.

\section{Sonuç ve Öneriler}

Sağlık kurumları emek yoğun hizmet veren kuruluşlar olup gün geçtikçe bu alanda artan bir rekabet ortamı oluşmaktadır. Bu rekabet ortamında rakiplerden önde olabilmek için örgütsel iklim ve örgütsel bağlllık kadar bu iki kavramı etkileyen faktörler de oldukça önemlidir. Bu çalışmada örgütsel iklim ve alt boyutları katılım ve bağlılı̆ın sağlık çalışanlarının demografik özelliklerine göre farklılık gösterip göstermediği incelenmiştir. Örgütsel iklim ölçeği ve alt boyut puanları normal dağılım gösterdiğinden cinsiyet, medeni durum, yaş, öğrenim düzeyi, kadro durumu, kıdem, kamuda çalışma süresi, toplam aylık gelir değişkenlerine göre karşılaştırılmıştır. Bunun için $\mathrm{t}$ testleri ve varyans analizi yapılmıştır.

Ölçek maddeleri için yapılan testlerde çalışanların genel olarak yöneticilerinden memnun olduğu görülmüştür. Kadınların örgütsel bağlılı̆̆ının erkeklere göre daha yüksek olduğu anlaşılmıştır. Kıdemi fazla olan çalışanlar yöneticilerin fikirlerine değer verip uyguladıklarını düşünmektedirler. Çalışanların gelir düzeyinin artmasının yönetimden memnuniyetlerinin de artmasına sebep olduğu anlaşılmaktadır.

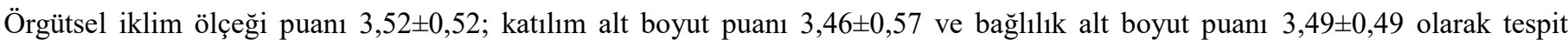
edilmiştir. Ölçek ve alt boyutları için alınabilecek en düşük (1) ve en yüksek (5) puanlar dikkate alındığında katılımcıların örgütsel iklim ve alt boyutları katılım ve bağlılık algısının "yüksek düzeyde olumlu" olduğu söylenebilir.

Örgütsel iklim ölçeği ve alt boyut puanlarının katılımcıların cinsiyetine ve medeni durumuna göre anlamlı farklılık göstermediği tespit edilmiştir. Buna göre örgütsel iklim algısı sağlık çalışanların erkek ya da kadın olmasına, evli ya da bekâr olmasına göre değişmemektedir. Benzer şekilde sağlık çalışanlarının örgütsel bağlılık düzeylerinde cinsiyetin anlamlı bir fark oluşturmadığ 1 belirtilmiştir (Özdemir, 2006; Akbolat ve ark., 2015). Ayrıca örgütsel iklim ölçeği ve alt boyut puanlarının katılımcıların yaş gruplarına, öğrenim düzeyine, mesleki kıdemine, kamuda çalışma süresine göre anlamlı farklılık göstermediği tespit edilmiş̧ir. Çalışmada çalışanların öğrenim düzeyine göre örgütsel bağlllıklarında istatistiksel olarak anlamlı bir farklılık bulunmasa da literatürde tersi sonuçlara da rastlanmıştır (Tekingündüz ve Tengilimoğlu, 2013; Akbolat ve ark., 2016).

Örgütsel iklim ölçeği ve alt boyut puanlarının katılımcıların kadro durumuna göre anlamlı farklılık gösterdiği tespit edilmiştir. Sağlık hizmetleri kadrosunda yer alan katılımcıların katılım alt boyut puanları, idari hizmetler ve yardımcı hizmetler kadrolarındaki katılımcıların puanlarından anlamlı düzeyde yüksektir.

Örgütsel iklim ölçeği katılım alt boyutu puanlarının gelir düzeyine göre anlamlı farklılıklar gösterdiği tespit edilmiştir ( $\mathrm{F}=5,37$; $\mathrm{p}<0,05)$. Aylık geliri 4000 TL'nin üstünde olan çalışanların katılım alt boyutu puanları, geliri 4000 TL'nin altında olanlara göre anlamlı düzeyde daha yüksektir. Şu halde gelir düzeyinin yükselmesine paralel olarak kişilerin örgütsel iklim algı puanlarında da bir artış gözlenmektedir.

Yapmış olduğumuz bu çalışma İstanbul ilinde Kamu Hastaneleri Birliğine bağlı hastane personelini kapsamaktadır. Çalışmanın daha kapsamlı ve genelleyici sonuçlara ulaşabilmesi için daha geniş bir yelpazede yapılması faydalı olacaktır. Bu bağlamda çalışma kamu hastanelerinin yanı sıra özel hastaneleri de kapsayacak şekilde genişletilerek karşılaştırmalı analizler yapılabilir. Öte yandan çalışma il bazında yapılabileceği gibi daha geniş bir çerçevede bölge ve ülke bazında yapılarak genişletilebilir.

\section{Kaynakça}

Acaray, A. \& Pelenk, S. E. (2018). İşe adanmışlığın güçlendirme iklimi ve bireysel performans ile ilişkisinin incelenmesi: hizmet sektöründe bir araştırma. İnsan ve Toplum Bilimleri Araşttrmaları Dergisi, 7(5), 154-177.

Ak, M. (2018). Kamu sağlık sektöründe örgütsel iklim analizi: Bartın 112 istasyonları örneği. C.Ü. Íktisadi ve İdari Bilimler Dergisi, 19(2), 340-371.

Akbolat, M., Işık, O. \& Tengilimoğlu, D. (2015). Personel uygulamalarının örgütsel bağlllık ve örgütsel bağlılığın iş tatminine etkisi. İş, Güç Endüstri İlişkileri ve İnsan Kaynakları Dergisi, 17(2), 3-37.

Akbolat, M., Kahraman, G. \& Öztürk, T. (2016). Sağlık çalışanlarının iş yaşamlarında karşılaştıkları iş aile çatışması örgütsel bağll1ıklarını etkiler mi? Sakarya ili örneği. Hacettepe Sağllk İdaresi Dergisi, 19(2), 153-169.

Akgemci, T., Abdul-Kareem, A. \& Kızıloğlu, E. (2020). Örgüt ikliminin örgüt temelli özsaygı ve öznel iyi oluş üzerindeki etkisi: Kobi'ler üzerinde bir araştırma. İşletme Araştırmaları Dergisi, 12(1), 65-78.

Aşık, N. A. (2018). Örgüt iklimi ve işe yabancılaşma ilişkisini belirlemeye yönelik bir araştırma. Güncel Turizm Araştırmaları Dergisi, 2(1), 29-41.

Baş, T., Amarat M., Ünal, Ö., Durmuş A. \& Boz, Ş. (2018). Örgütsel iklimin örgütsel bağlilığa etkisi: Özel hastane örneği. Mehmet Akif Ersoy Üniversitesi İktisadi ve İdari Bilimler Fakültesi Dergisi, 5(3), 538-548.

Bulşu, Ç. \& Gümüş, M. (2018). Farklılıkların yönetimi ve örgütsel bağllı̆̆ı̆ın işten ayrılma niyetine etkisi. Journal of Tourism and Gastronomy Studies, 6(4), 322-344.

Büyüköztürk, Ş. (2011). Sosyal Bilimler İçin Veri Analizi El Kitabı (14. Baskı). Ankara: Pegem Akademi.

Çelik, H. (2012). Aile hekimliğinde çalışan sağllk personelinin örgütsel bă̆lllık ve iş tatmini ilişkisi üzerine bir araştırma. (Yayınlanmamış Yüksek Lisans Tezi). İstanbul Üniversitesi, İstanbul.

Deniz, M. \& Çoban R. (2016). Örgütsel iklimin çalışan bağllı̆̆ğna etkisi ve bir araştırma. Birey ve Toplum Sosyal Bilimler Dergisi, 6(2), 49-72. 
Demirbaş, Z. (2017). Sağllk işletmelerinde örgüt iklimi ve çalışan memnuniyeti ilişkisi üzerine bir araştırma. (Yayınlanmamış Yüksek Lisans Tezi). İstanbul Ticaret Üniversitesi, İstanbul.

Ertem, H. Y. \& Gökalp, G. (2019). Lisansüstü eğitim'de örgüt iklimi ölçeği'nin geliştirilmesi. İnönü Üniversitesi Eğitim Fakültesi Dergisi, 20(3), 784-797.

Erturk, A. \& Ziblım, L. (2020). Is the perception of organizational deviation affected by the organizational climate? Research in schools. Eurasian Journal of Educational Research, 20(85), 1-22.

Fabiene, E. E. \& Kachchhap, S. L. (2016). Determinants of employee's commitment among healthcare professionals. International Journal of Academic Research in Accounting, Finance and Management Sciences, 6(2), 44-52.

Filiz, M. \& Bardakçı, S. (2020). Sağlık çalışanlarının örgütsel iklim algıları ve örgütsel güven düzeyleri arasındaki ilişkinin incelenmesi: Artvin ili örneği. Elektronik Sosyal Bilimler Dergisi, 19(73), 436-449.

Göreci, E. (2019). Örgütlerde farklılıkların yönetiminin örgüt iklimi üzerine etkisinin araştırılması. Journal of International Social Research, 12(64), 743-755

Güçlü, N. (2003). Örgüt kültürü. Gazi Üniversitesi Sosyal Bilimler Dergisi, 23(2), 61-85.

Günay, G. Y., Demiralay, T. \& Gürkan, G. Ç. (2017). Örgütsel iklimin işkoliklik üzerindeki etkileri: Türk zincir otel yöneticileri üzerinde bir araştırma. Kocaeli Üniversitesi Sosyal Bilimler Dergisi, 33, 87-104.

Güner, F. (2015). Çalışma hayatında örgütsel iklim ve iş doyumu. (Yayınlanmamış Yüksek Lisans Tezi). Beykent Üniversitesi, İstanbul.

Gürkan, G. Ç. \& Koçoğlu, M. (2014). Yaratıcı örgüt ikliminin iş tatmini üzerinde duygusal bağlılığın aracı değişken rolü: Türkiye'de bir vakıf ve bir devlet üniversitesinde karşılaştırmalı bir araştırma. Uluslararası Sosyal Araşstırmalar Dergisi, 29(7), 588-602.

Hashemi, J. \& Sadeqi, D. (2016). The relationship between job satisfaction and organizational climate: A case study of government departments in divandarreh. World Scientific News, 45(2), 373-383.

İşcan, Ö. F. \& Karabey, C. N. (2007). Örgüt iklimi ile yeniliğe destek algısı arasındaki ilişsi. Gaziantep Üniversitesi Sosyal Bilimler Dergisi, 2(2), 180-193.

Karcıoğlu, F. (2001). Örgüt kültürü ve örgüt iklimi ilişkisi. Atatürk Üniversitesi İktisadi ve İdari Bilimler Dergisi, 15(1-2), 265-283.

Kılıç, M. Y. (2019). Okullarda yöneticinin sağladığı etik iklimin, örgütsel bağlılık ve öğretmen performansına etkisi. Cumhuriyet Uluslararası Ë̆itim Dergisi, 8(3), 807-836.

Mikail, E. H. \& Çora, H. (2020). Örgüt ikliminin özel sağlık sektöründe hizmet kalitesi üzerine yansımalarına ilişkin bir çalışma. Turkish Studies, 15(1), 481-498.

Mullins, L. J. (2007). Management and Organizational Behaviour. London: Prentice Hall.

Nair, R. (2006). Climate studies and associated best practices to improve climate issues in the workplace. Proceedings of the 2006, WEPAN Conference, WEPAN-Woman in Engineering Programs and Advocates Network.

Nojehdehi, M. M., Farahani, M. A., Rafii, F. \& Bahrani, N. (2016). A comparison of organizational climate and nurses' intention to leave among excellence awarded hospitals and other hospitals in 2013. Iran Red Crescent Med J., 17(5), 1-6.

Örgev, C. \& Sütlü, E. S. (2018). Sağlık çalışanlarının hizmetkâr liderlik algılarının örgüt iklimi ve örgütsel bağlllık üzerine etkileri: Bir kamu hastanesi örneği. Sağgllk Akademisyenleri Dergisi, 5(1), 47-53.

Özdemir, F. (2006). Örgütsel iklimin iş tatmin düzeyine etkisi: Tekstil sektöründe bir araştırma. (Yayınlanmamış Doktora Tezi). Çukurova Üniversitesi, Adana.

Öztek, S. (2006). Sağllk Işsletmeleri, Ankara: Seçkin Yayıncılık.

Permarupan, P. Y., Saufi, R. A., Kasim, R. S. R. \& Balakrishnan, B. K. (2013). The impact of organizational climate on employee's work passion and organizational commitment. Procedia-Social and Behavioral Sciences, 107, 88-95.

Saraç, K. (2015). Okul ikliminin ortaokul öğrencilerinin algllarına göre değerlendirilmesi. (Yayınlanmamış Yüksek Lisans Tezi). Eskişehir Osmangazi Üniversitesi, Eskişehir.

Sarı, T. (2019). Okul yöneticilerinin algl yönetimi taktikleri, örgüt iklimi ve öğretmen motivasyonu arasındaki ilişkiler. (Yayınlanmamış Yüksek Lisans Tezi). Pamukkale Üniversitesi, Denizli.

Taymaz, H. (2003). Okul Yönetimi, Ankara: Pegem Yayınları.

Tekingündüz, S. \& Tengilimoğlu, D. (2013). Hastane çalışanlarının iş tatmini, örgütsel bağlllık ve örgütsel güven düzeylerinin belirlenmesi. Sayıştay Dergisi, 91, 77-103.

Tsai, C. (2014). The organizational climate and employees' job satisfaction in the terminal operation context of kaohsiung port. The Asian Journal of Shipping and Logistics, 30(3), 373-392.

Tutar, H. (2016). Örgütsel Davranış (Örgüt Teorileri ve Çağdaş Yaklaşımlar Açısından). 1.baskı. Ankara: Detay Yayıncılık.

Tutar, H. \& Altınöz, M. (2010). Örgütsel iklimin işgören performansı üzerine etkisi: Ostim imalât işletmeleri çalışanları üzerine bir araştırma. Ankara Üniversitesi SBF Dergisi, 65(2), 195- 218.

Uysal, H. T. (2013). Stajyer çalışanların mesleki bağlllık gelişimine örgüt ikliminin etkisi. Business and Economics Research Journal, 4(3), 93-110.

Yağcl, K. (2007). Meyer-Allen örgütsel bağlılık modeli yaklaşımıyla otel işletmeleri işgörenlerinin örgütsel bağl1lık düzeylerinin ölçülmesine yönelik bir araştırma. Dokuz Eylül Üniversitesi Sosyal Bilimler Enstitüsü Dergisi, 9(3), 114-129.

Yalçınsoy, A. (2016). Örgüt kültürü ve örgüt ikliminin örgütsel sessizlik üzerindeki etkisinin analizi. Anemon Muş Alparslan Üniversitesi Sosyal Bilimler Dergisi, 7(2), 67-77.

Yeniçeri, T. \& Yücel, İ. (2009). Müşteri ilişkileri, örgütsel bağlılık, planlama, öğrenme yönlülük, uyum sağlayıcı davranış ile satış performansı arasındaki ilişkinin incelenmesi. C.Ü İktisadi ve İdari Bilimler Dergisi, 10(1), 137-157.

Yüceler, A. (2009). Örgütsel bağll1ık ve örgüt iklimi ilişkisi: teorik ve uygulamalı bir çalışma. Selçuk Üniversitesi Sosyal Bilimler Enstitüsü Dergisi, 446-457.

Yüksekbilgili, Z. \& Küçükozan, Y. (2017). Sağlık işletmlerinde örgüt iklimi ile çalışanların iş performansı arasındaki ilişkinin incelenmesi. Süleyman Demirel Üniversitesi Vizyoner Dergisi, 8(17), 34-46. 